\title{
Drug Resistance of Ocular Bacteria Considering Biofilm Mechanism
}

\author{
Yutong $\mathrm{LIU}^{1 *}$, Xuanrong XU1 \\ ${ }^{1}$ Tianjin Medical University
}

\begin{abstract}
In order to further analyze the relationship between the coating mechanism of microorganisms and their drug resistance, a study of ocular bacterial drug resistance considering the coating mechanism of microorganisms was proposed. Firstly, the mechanism of drug resistance was analyzed, and on this basis, the experimental study was carried out. Staphylococcus aureus DH5 with RP4 was used as the control $\alpha(\mathrm{R})$ Objective to investigate the relationship between drug-resistant bacteria and coating mechanism in the cross genus conjugation system of Pseudomonas aeruginosa PAOi and donor bacteria. The conclusion is that: under the condition that the horizontal transfer of drug-resistant genes between transgeneric bacteria in biofilm is inhibited, the frequency of drug-resistant gene conjugation and transfer gradually decreases, and the inhibition of the formation of drug-resistant bacterial biofilm will directly lead to the decrease of bacterial drug resistance.
\end{abstract}

\section{INTRODUCTION}

Whether it is a common antimicrobial or a new type of antimicrobial, the resistance of bacteria to them is increasing.Firstly, for example, in 1939, the treatment of pneumonia with penicillin of 80000 international units had good effect. In 1970, 10 times more penicillin was needed to get the same effect. Only by 100 times of penicillin in the early 21 st century can it be effective ${ }^{[1-2]}$; Secondly acterial resistance can increase the mortality and incidence of infectious diseases. According to the World Health Organization, M. tuberculosis with multiple drug resistance increased the mortality rate by at least $1 / 3$, while the Enterobacteriaceae bacteria resistant to broad-spectrum carbapenems increased the mortality rate of infected persons by half [3-4]; Third, drug resistance leads to huge economic losses. In Europe, the economic losses caused by bacterial resistance amounted to 1.5 billion euros. Finally, bacterial resistance is also a disaster in modern medicine. Whether in clinic or in aquaculture, antibiotic treatment is still the first choice for bacterial infection. [5-6].

With the widespread use of antimicrobial agents, bacteria will produce resistance to each antimicrobial drug, which is the general rule of nature [7-8]. The mechanism of bacterial resistance is a complex and dynamic process, which is regulated by many aspects, including the function, heredity and environmental factors of bacteria [9-10]. To understand the research status of drug resistance mechanism is of great significance to prevent and control bacterial resistance and effective treatment of infectious diseases caused by drug-resistant bacteria. According to the research, the drug resistance mechanism of bacteria includes genetic mechanism and biochemical mechanism, and these two mechanisms have been studied thoroughly. Among them, the genetic resistance mechanism of bacteria can be divided into innate and acquired resistance[11-13]. Pneumococcus can produce cephalosporin enzyme, which makes it resistant to penicillin [14-16]. According to the reasons of bacterial resistance, the mechanism of biochemical resistance can be divided into: inactivated enzyme or passivation enzyme produced by bacteria. This mechanism of resistance is one of the most important mechanisms of bacteria. Inactivated enzymes or passivation enzymes produced by bacteria are mainly $\beta$ - The antibiotics inactivate or destroy the lactamase, aminoglycoside modified enzyme, acetyltransferase, etc. before they can play the role of sterilization or bacteriostasis; Change the permeability barrier of bacterial cell membrane. The pore protein on the extracellular membrane is a non-specific, transmembrane water-soluble channel protein, and is the natural barrier for antibiotics to enter bacteria. If the pore protein of the bacteria changes, the antibiotics also lose access to the bacteria. Based on this, this paper proposes a study on the drug resistance of eye bacteria considering the mechanism of microbial membrane. The effect intensity of the coated membrane was analyzed by the experimental method, so as to judge the change of drug resistance of eye bacteria.

\footnotetext{
* Corresponding author: xuxuanrong19990828@126.com
} 


\section{ANALYSIS OF THE MECHANISM OF RESISTANCE OF BACTERIAL BIOFILM}

The drug resistance mechanism of biofilm is as follows:

(1) Antibiotics can not penetrate biofilm

Extracellular polysaccharide matrix produced by biofilm is one of its remarkable characteristics. It provides a kind of permeability barrier to prevent antibiotics from entering bacterial cells wrapped in biofilm ${ }^{[17]}$.

(2) Slow growth and response to stress

In mature organisms, bacteria will enter a slow growth state due to the influence of nutritional restriction. Compared with the normal growth state, the sensitivity of bacteria to antimicrobial agents was lower when the growth rate of biofilm was slow. When the external environment changes, bacteria will produce many stress responses, which can be used in biofilm as well. RpoS is a stress response regulatory factor expressed by gram-negative bacteria. It can increase the tolerance of biofilm by regulating the growth rate of bacteria.

(3) Heterogeneity and persistent

Biofilm is a very complex group. The differentiation of cells results in a gradual decrease in oxygen and nutrition gradient between the surface and the deep layer of the biofilm. Results: when faced with antimicrobial agents, the cells with more active surface metabolism showed different reactions compared with those of the cells with less nutrition, oxygen and slow growth. PAMP and others used ciprofloxacin to treat the biofilm of Pseudomonas aeruginosa. It was found that only cells with high metabolism or physiological activity could be killed.

The remaining bacteria are a kind of cell in dormant state, which exist in plankton and biofilm, but the number of bacteria is much more than that of plankton. In the bacteria, the cell metabolism activity is very slow or even closed, creating a situation where antibiotics can not function and can bear the antibiotic concentration that can inhibit the growth of bacteria. Therefore, the existence of this kind of bacteria also caused the strong resistance of biofilm.

(4) Quorum sensing (QS)

In biofilm, bacteria communicate with bacteria by spontaneously producing and releasing specific signal molecules. This phenomenon is called group induction. QS is a small molecular weight limb in Gram-positive bacteria, while $\mathrm{N}$-acyl high serine lactone is found in Gram-negative bacteria. In Pseudomonas aeruginosa, QS can not only regulate the production of virulence factors, but also improve the tolerance of biofilm to antibiotics.

\section{RESEARCH MATERIALS}

\subsection{Experimental instruments and materials}

The instrument, equipment, materials and preparation solutions used in the experiment are shown in table 1 , table 2 and table 3 respectively
Tab. 1 Experimental equipment and instruments

\begin{tabular}{|c|c|c|}
\hline Name & Specifications & Manufacturer \\
\hline $\begin{array}{l}\text { Constant temperature } \\
\text { magnetic stirring rod }\end{array}$ & RCT & IKA \\
\hline $\mathrm{PH}$ & PSH-3C & $\begin{array}{l}\text { Shanghai } \\
\text { Zhicheng }\end{array}$ \\
\hline $\begin{array}{l}\text { Electronic analytical } \\
\text { balance }\end{array}$ & ME203 & $\begin{array}{l}\text { METLER } \\
\text { TOLEDO }\end{array}$ \\
\hline $\begin{array}{l}\text { Dual frequency } \\
\text { ultrasonic cleaner }\end{array}$ & KQ-600GKDV & $\begin{array}{l}\text { Shanghai } \\
\text { Zhicheng }\end{array}$ \\
\hline Gas bath constant & ZD85A & Shanghai \\
\hline $\begin{array}{l}\text { temperature oscillator } \\
\text { Ultraviolet visible } \\
\text { spectrophotometer }\end{array}$ & UV-2000 & $\begin{array}{l}\text { Zhicheng } \\
\text { unique }\end{array}$ \\
\hline Vibration incubator & ZZY-CG8 & Zhichu instrument \\
\hline $\begin{array}{l}\text { Constant temperature } \\
\text { culture dish }\end{array}$ & ZWY-2112B & $\begin{array}{l}\text { Shanghai } \\
\text { Zhicheng }\end{array}$ \\
\hline Ultra clean worktable & SW-CJ-2FD & $\begin{array}{l}\text { Shanghai } \\
\text { Zhicheng }\end{array}$ \\
\hline $\begin{array}{l}\text { Vertical high pressure } \\
\text { steam sterilization pot }\end{array}$ & LDZX-50KBS & $\begin{array}{l}\text { Shanghai } \\
\text { Zhicheng }\end{array}$ \\
\hline Gel electric ice device & DYCP-31BN & $\begin{array}{l}\text { Shanghai } \\
\text { Zhicheng }\end{array}$ \\
\hline Gel electrophoresis cell & DYCP-31BN & $\begin{array}{l}\text { Shanghai } \\
\text { Zhicheng }\end{array}$ \\
\hline $\begin{array}{l}\text { Small high speed } \\
\text { centrifuge }\end{array}$ & CEN5418 & Eppendorf \\
\hline $\begin{array}{l}\text { High speed freezing } \\
\text { centrifuge }\end{array}$ & $3 \mathrm{~K} 15$ & Signa \\
\hline Microplate Reader & SPARK & Deacon business \\
\hline $\begin{array}{l}\text { Real time fluorescence } \\
\text { quantificationPCR }\end{array}$ & QUAN5 & $\begin{array}{l}\text { Thermo Fisher } \\
\text { Scientific }\end{array}$ \\
\hline $\begin{array}{l}\text { Ultramicro } \\
\text { spectrophotometer }\end{array}$ & NANODROP1 & $\begin{array}{l}\text { Thermo Fisher } \\
\text { Scientific }\end{array}$ \\
\hline Polystyrene microplate & 96 holes & Kangning \\
\hline
\end{tabular}

Tab.2 Main materials and chemical reagents

\begin{tabular}{|c|c|c|}
\hline Name & Specifications & Manufacturer \\
\hline methanol & Analytically pure & $\begin{array}{c}\text { Sinopharm } \\
\text { Chemical Reagen } \\
\text { Co., Ltd }\end{array}$ \\
\hline $\begin{array}{l}\text { Crystal violet } \\
\text { solution }\end{array}$ & $0.1 \%$ & Solarbio \\
\hline Glacial acetic acid & Analytically pure & $\begin{array}{c}\text { Sinopharm } \\
\text { Chemical Reagen } \\
\text { Co., Ltd }\end{array}$ \\
\hline $\begin{array}{c}\text { Tryptone } \\
\text { yeast extract }\end{array}$ & $\begin{array}{l}\text { Analytically pure } \\
\text { Analytically pure }\end{array}$ & $\begin{array}{l}\text { Oxoid } \\
\text { Oxoid }\end{array}$ \\
\hline sodium chloride & Analytically pure & $\begin{array}{c}\text { Sinopharm } \\
\text { Chemical Reagen } \\
\text { Co., Ltd }\end{array}$ \\
\hline $\begin{array}{l}\text { Disodium } \\
\text { hydrogen } \\
\text { phosphate }\end{array}$ & Analytically pure & $\begin{array}{c}\text { Sinopharm } \\
\text { Chemical Reagen } \\
\text { Co., Ltd }\end{array}$ \\
\hline $\begin{array}{l}\text { Potassium } \\
\text { dihydrogen } \\
\text { phosphate }\end{array}$ & Analytically pure & $\begin{array}{c}\text { Sinopharm } \\
\text { Chemical Reagen } \\
\text { Co., Ltd }\end{array}$ \\
\hline potassium chloride & Analytically pure & Sinopharm \\
\hline Vanillin & Analytically pure & $\begin{array}{c}\text { Chemical Reagen } \\
\text { Co., Ltd } \\
\text { Sinopharm } \\
\text { Chemical Reagen } \\
\text { Co., Ltd }\end{array}$ \\
\hline
\end{tabular}


Tab. 3 Preparation of antibiotic stock solution

\begin{tabular}{ccc}
\hline Name of antibiotics & $\begin{array}{c}\text { Stock solution } \\
\text { concentration } \\
(\mathrm{g} / \mathrm{L})\end{array}$ & Stock solvent \\
\hline Ampicillin & 100 & $\begin{array}{c}\text { sterile water } \\
\text { sterile water } \\
\text { ethanol }\end{array}$ \\
$\begin{array}{c}\text { Kanamycin } \\
\text { Tetracycline } \\
\text { hydrochloride } \\
\text { chloramphenicol }\end{array}$ & 50 & $\begin{array}{c}\text { ethanol+sterile } \\
\text { water }\end{array}$ \\
\hline
\end{tabular}

After the preparation of antibiotic reserve solution, the reserve solution is absorbed with syringe, filtered by $0.22 \mathrm{um}$ filter head, and then the antibiotic solution is separately packed into $1.5 \mathrm{ml}$ or $2 \mathrm{ml}$ sterilized centrifugal tube, and wrapped in tin foil paper to avoid light, and stored in refrigerator at $-20{ }^{\circ} \mathrm{C}$, and melted at room temperature in advance before use, and the reserve solution is diluted to the experimental concentration for experiment.

Preparation of LB liquid medium: weigh $10 \mathrm{~g}$ of trypsin aging, $5 \mathrm{~g}$ yeast powder, $10 \mathrm{~g}$ sodium chloride into $100 \mathrm{oml}$ beaker, add about $800 \mathrm{ml}$ of deionized water, stir to make it fully dissolved, then fix the volume to $1000 \mathrm{ml}$, and then divide it into $250 \mathrm{ml}$ conical bottle or $500 \mathrm{ml}$ blue mouth bottle. After sealing the sealing film or tin foil paper, put it into the autoclave for $121 \mathrm{c}$ for $25 \mathrm{~min}$.

Preparation of LB agar medium: the composition of the above-mentioned LB liquid medium is exactly the same. Add $3 \mathrm{G}$ agar powder to every $200 \mathrm{ml}$ of LB liquid medium, sterilize it at $121{ }^{\circ} \mathrm{C}$ for 25 minutes, and cool it to $55^{\circ}$ Pour into sterile culture dish at ${ }^{\circ} \mathrm{C}$ and store it in refrigerator at $4{ }^{\circ} \mathrm{C}$ after it is cooled to solidification.

Preparation of antibiotic LB agar medium: after autoclave, the medium is cooled for standby. After cooling to about $55^{\circ} \mathrm{C}$, add the antibiotics and mix them well before pouring it to the plate.

Preparation of PBS buffer solution: weigh $8 \mathrm{~g} \mathrm{NaCl}$, $0.2 \mathrm{~g} \mathrm{KCI}, 1.42 \mathrm{~g}$ nahpo $4,0.27 \mathrm{~g}$ khzpo 4 in $1000 \mathrm{ml}$ beaker, add about $800 \mathrm{ml}$ of deionized water to stir well, add concentrated hydrochloric acid to adjust $\mathrm{pH}$ value to 7.2-7.4, then use deionized water to determine the volume to $1000 \mathrm{ml}$, and sterilize it at $121{ }^{\circ} \mathrm{C}$ for 25 minutes, and then keep it for use.

Preparation of different concentrations of vanillin solution: weigh different quality vanillin reagent to dissolve in DMSO, and after it is completely dissolved, it will be separated by membrane and placed in refrigerator at $4{ }^{\circ} \mathrm{C}$.

\subsection{Experimental plasmids, strains and culture}

RP4 plasmid: the RP4 plasmid used in the experiment is from the gift of the Institute of microbial technology of Shandong University. The plasmid, which carries the resistance genes of ampicillin, kanamycin and tetracycline, is a shuttle plasmid, which can transfer water between many bacteria. The plasmid was used before $-80^{\circ} \mathrm{C}$ refrigerators for storage.

Experimental strains and culture conditions: Staphy lococcus aureus DH5 containing RP4 plasmid will be used in this chapter $\alpha$ As a donor bacteria, it can resist ampicillin, kanamycin and tetracycline; PAO1, a Pseudomonas aeruginosa with chloramphenicol resistance, was used as the receptor bacteria. The experimental strains were cultured in LB liquid medium, and the corresponding antibiotics were added to screen the correct strains. The culture medium was placed in $37 \mathrm{C}$ constant temperature oscillator, with a speed of $180 \mathrm{rpm}$ and overnight culture for $16-18 \mathrm{~h}$.

\subsection{Drawing of growth curve}

To further verify whether the subclinic concentration gradient set is true for Staphy lococcus aureus DH5 $\alpha(\mathrm{R})$ The growth curves of Staphy lococcus aureus dh5a (R) and PAO1 were measured under the influence of vanillin in the subbacteriostatic concentration.

(1) The initial Staphy lococcus aureus dh5a (R) and PAO1 bacteria solution were diluted to about 0.5 with PBS buffer solution;

(2) In the sterile conical flask sterilized by high pressure, add $100 \mathrm{ml}$ of LB liquid medium, inoculate the diluted bacteria solution into the medium, and then add different concentrations of vanillin solution respectively to make the final concentration of $0,0.025,0.05,0.1,0.2,0.4,0.8 \mathrm{~g} / \mathrm{l}$. Seal the conical bottle with sealing film and place it in $37^{\circ}$ The shaking table was cultured at $180 \mathrm{rpm}$ for 24 hours;

(3) Take 400ul bacteria solution every two hours in sterile $2 \mathrm{ml}$ centrifuge tube, dilute it with deionized water for 5 times and mix it evenly, and measure the OD value at $600 \mathrm{~nm}$ on the spectrophotometer;

(4) Organize the data measured at each time point and draw the growth curve.

\subsection{Culture of biofilm and determination of its content}

The formation of biofilm was determined by the method of crystal violet staining.

The culture of the biofilm of drug resistant strains was completed in polystyrene 96 pore board, and the specific experimental steps were as follows:

(1) The concentration of PAO1 was adjusted to 0.03 in od6oo by LB liquid medium.

(2) add 198jul diluted PAO1 bacteria solution and 2 UL of vanillin solution $(0,0.025,0.05,0.1,0.2,0.4,0.8 \mathrm{~g} / \mathrm{l})$ in each hole of 96 hole plate, and make at least 7 multiple holes respectively. The control group was 200 UL LB medium;

(3) Put it in $37^{\circ} \mathrm{C}$ for 13 hours.

(4) The culture solution was sucked out along the wall of the hole, and 200 UL sterile PBS buffer (or sterile water) was added to each hole to clean the plate hole for 3 times, and the bacteria without adsorption were removed and dried;

(5) Each hole is fixed with 180 UL methanol for 15 minutes, then the methanol in each hole is sucked out and dried naturally ( 6) add 200 UL $0.1 \%$ crystal violet solution to each hole and place it at room temperature for $20 \mathrm{~min}$ 
(7) Suck out the dye solution in the culture hole, add sterile water for 3-5 times, and wash the excess dye as far as possible; Remove the residual water from the culture plate, and then dry it in a room temperature or in a $37^{\circ} \mathrm{C}$ oven;

(8) After drying, $200 \mathrm{UL} 33 \%$ of glacial acetic acid solution was added to each culture hole, and 30 minutes was placed in the incubator at $37{ }^{\circ} \mathrm{C}$ to completely dissolve the crystal violet

(9) The ods0 value of 96 hole plate culture was determined by enzyme standard instrument at $590 \mathrm{~nm}$.

\section{Results and discussion}

\subsection{Results of transformation of Staphylococcus aureus with RP4 plasmid}

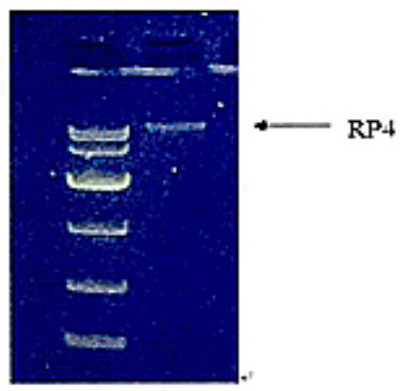

Fig. 1 Electrophoresis of RP4 plasmid transformation of Staphylococcus aureus

Fig. 1 shows plasmid transformation gel electrophoresis. Only when RP4 plasmid is successfully introduced into Staphy lococcus aureus DH5 $\alpha$ Staphy lococcus aureus DH5 $\alpha$ To grow on resistant plates containing three antibiotics. A single colony was picked up on the resistant plate, and then plasmid was extracted after overnight cultivation. The gel electrophoresis showed that an obvious electrophoretic strip appeared at about $60 \mathrm{~K}$, that is, RP4 plasmid strip, which proved that RP4 plasmid had successfully transformed into Staphy lococcus aureus DH5a. For the convenience of the following description, the dhsa of Staphylococcus aureus containing RP4 plasmid was named Staphy lococcus aureus dh5a (R).

\subsection{Determination of QS related gene expression level}

In order to determine the effect of Vanillin on QS system of Pseudomonas aeruginosa, we used RT qPCR to determine the expression levels of LAS and RHL system related genes in PAO1 quorum response system under the influence of vanillin. As shown in Fig. 6 and Fig. 7, the expression of Lasi and lasr genes in Las system and rhli and rhlr genes in RHL system were inhibited and the expression level was down regulated after adding vanillin of sub inhibitory concentration. Compared with the control group, the inhibition rates of Lasi, lasr, rhli and rhlr were $19.2 \%, 33.5 \%, 23.4 \%$ and $27.2 \%$, respectively. Detection of 3.5 AHL signal molecules
Both Ca HSL and 3-oxo-ci2-hsl are key signaling molecules in the quorum sensing and effector system of Pseudomonas aeruginosa. Their synthesis is controlled by rhli and Lasi in PAO1 quorum sensing and effector system, respectively. The results of LC-MS / MS analysis of the signal molecules extracted from conjugated bacteria are shown in Figure 2. With the increase of vanillin concentration, the concentrations of the two signal molecules in conjugated bacteria gradually decrease. When the concentration of vanillin was $0.1 \mathrm{~g} / \mathrm{L}$, the content of Ca HSL and 3-oxo-c12-hsl in conjugation system decreased by $57.9 \%$ and $23.8 \%$ respectively compared with the blank control group. It can be seen that vanillin has inhibitory effect on the synthesis of c4-hsl and 3-oxo-c2-hsl, and the inhibitory effect on the synthesis of c4-hsl is stronger than that on the synthesis of 3-oxo-ci2-hsl.

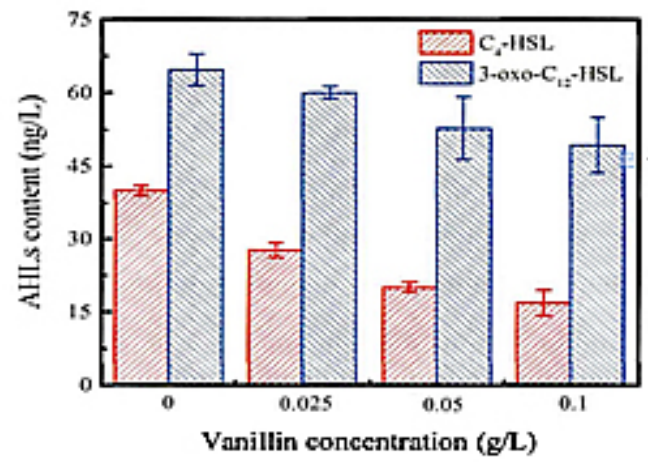

Fig.2 Effect of vanillin on the secretion of AHLs.

\subsection{Effect of Vanillin on biofilm formation of drug-resistant strains}

The effect of Vanillin on the content of Staphy lococcus aureus dh5a (R) biofilm is shown in Fig 3. Compared with the blank control group, Staphy lococcus aureus dh5a (R) biofilms treated with lower concentrations of vanillin showed a significant decrease in Staphy lococcus aureus DH5 $\alpha$ ( R) For example, when the concentration of vanillin was $0.025 \mathrm{~g} / \mathrm{L}$, the content of Staphy lococcus aureus dh5a (R) biofilm only decreased by $3.7 \%$, while when the concentration of vanillin increased to $0.1 \mathrm{~g} / \mathrm{L}$, the content of Staphy lococcus aureus dh5a (R) biofilm decreased by $3.7 \% \alpha(\mathrm{R})$ The content of biofilm was only reduced by $9.5 \%$. When the concentration of vanillin was $0.8 \mathrm{~g} / \mathrm{L}$, the content of Staphy lococcus aureus dh5a (R) biofilm decreased by $17.9 \%$. Therefore, the formation of Staphy lococcus aureus dh5a (R) biofilm was inhibited by vanillin with sub inhibitory concentration, but the inhibitory effect was not significant. 


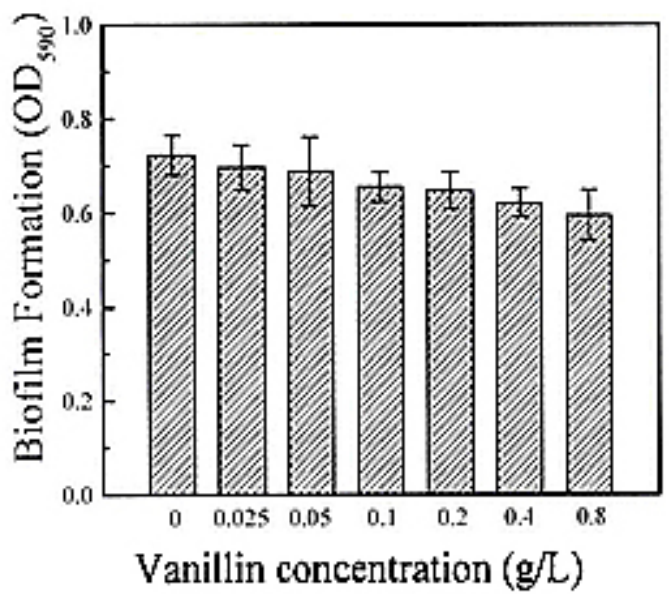

Fig. 3 Lnhibition of Staphy lococcus aureus DH5 $\alpha$ (R) biofilm formation by vanillin.

Pseudomonas aeruginosa PAO1 is a strong biofilm strain. As shown in Fig 4, vanillin with sub inhibitory concentration has obvious inhibitory effect on the formation of PAO1 biofilm. Compared with the blank control group, when the concentration of vanillin was $0.025 \mathrm{~g} / \mathrm{L}$, the content of PAO1 biofilm was significantly decreased, the decrease rate was about $20.5 \%$. With the increase of vanillin concentration, the ability of PAO1 to form biofilm gradually decreased, and the inhibitory effect of Vanillin on PAO1 biofilm formation gradually increased. When the concentration of vanillin reached $0.1 \mathrm{~g} / \mathrm{L}$, the content of PAO1 biofilm decreased by $32.4 \%$, and the inhibition rate of $0.8 \mathrm{~g} / \mathrm{L}$ Vanillin on the formation of PAO1 biofilm reached $46.7 \%$. It can be seen that vanillin has obvious inhibitory effect on the formation of PAO1 biofilm, and the inhibitory effect on the formation of PAO1 biofilm gradually increases with the increase of vanillin concentration.

The results show that lassr and rhlr genes play a role in the regulation of biofilm formation. Therefore, it can be concluded that vanillin can inhibit the formation of biofilm because it affects the expression of genes related to the group effect system.

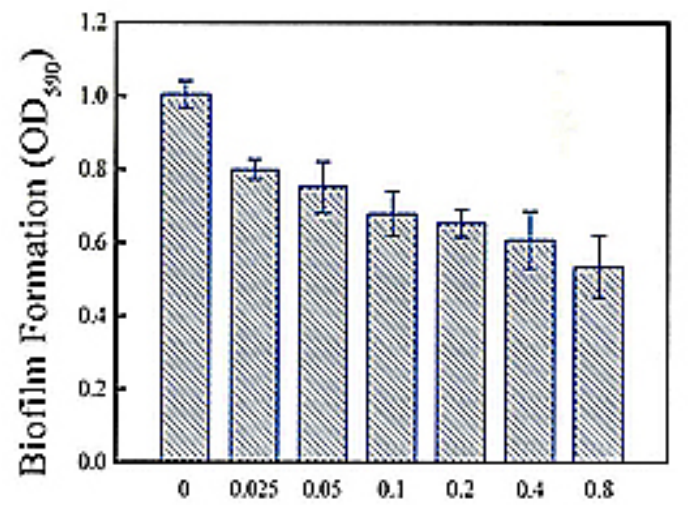

Vanillin concentration $(\mathrm{g} / \mathrm{L})$

Fig. 4 Effect of Vanillin on PAO1 biofilm formation

It can be seen from the comparison between Fig 4 and fig. 4 that the biomass of Staphy lococcus aureus dhsa (R) is $68.5 \%$ of PAO1 biofilm formation without vanillin under the same culture conditions. Therefore, the ability of Pseudomonas aeruginosa PAO1 to form biofilm is stronger than that of Staphy lococcus aureus dh5a (R).

\subsection{The effect of Vanillin on the binding and transfer of RP4 plasmid}

$0.025,0.05,0.1 \mathrm{~g} / 1$ of vanillin was selected as the experimental concentration in Staphy lococcus aureus dh5a (R) - PAO1 conjugation transfer system.

In the binding experiment, we observed that the acceptor bacteria were supplied with $37 \mathrm{cfu} / \mathrm{ml}$ of the initial concentration of the conjugating medium LB and the initial concentration of the conjugated bacteria solution. After 4 hours of static conjugation under $\mathrm{C}$, the mixed bacterial solution of Staphy lococcus aureus dh5a (R) and PAO1 had initially formed a drug-resistant bacterial biofilm. Therefore, the binding and transfer of RP4 plasmid was considered to occur in the biofilm.

\section{Conclusions}

In this paper, Staphylococcus aureus Staphy lococcus aureus DH5 containing RP4 was used in this paper $\alpha$ ( R) The effects of Vanillin on the group sensitivity of Pseudomonas aeruginosa were studied, including gene expression related to the group effect system and the influence on signal synthesis, The effects of Vanillin on the formation of biofilm and the frequency of RP4 plasmid conjugation and transfer were studied. The following conclusions are obtained:

(1) Vanillin has inhibitory effect on the formation of biofilm of drug-resistant strains, and it is inhibition of the formation of drug-resistant bacteria biofilm by inhibiting the expression of QS system genes rather than the growth of bacteria. The inhibition of Staphy lococcus aureus dh5a (R) biofilm formation was $17.9 \%$ and $46.7 \%$ on PAO1 biofilm formation when the maximum concentration was $0.8 \mathrm{~g} / 1$, but had no effect on the growth of two planktonic bacteria.

(2) The subbacteriostatic concentration of vanillin can effectively inhibit the horizontal transfer of resistance genes among bacteria in biofilm. In the process of the binding of recipient bacteria, we observed that the biofilm had been formed in the binding system. Therefore, the binding and transfer of RP4 plasmid was considered to occur in the biofilm. The results showed that the frequency of plasmid conjugation and transfer decreased with the increase of vanillin concentration, and did not affect the growth of PAO1.

Therefore, we believe that vanillin with subbacteriostatic concentration can inhibit the formation of bacterial biofilm by inhibiting the expression of Lassi, lassr, rhll, rhlr genes and the synthesis of C4 HSL and 3-oxo-c2-hsl. However, the formation of biofilm of drug-resistant bacteria is inhibited, which plays an active role in preventing the transfer and diffusion of drug-resistant genes. 


\section{Reference}

1. R Rodríguez-García, Volkov V A, Chen C Y, et al. Mechanisms of Motor-Independent Membrane Remodeling Driven by Dynamic Microtubules[J]. Current Biology, 2020, 30(6):972-981.

2. Huang H W . DAPTOMYCIN, its membrane-active mechanism vs. that of other antimicrobial peptides $[\mathrm{J}]$. Biochimica et Biophysica Acta (BBA) Biomembranes, 2020, 1862(10):183395.

3. Tadej, Kotnik, Lea, et al. Membrane Electroporation and Electropermeabilization: Mechanisms and Models.[J]. Annual Review of Biophysics, 2019, 48(6):63-91.

4. Evans J P . Preventing polyspermy in mammalian eggs-Contributions of the membrane block and other mechanisms[J]. Molecular Reproduction and Development, 2020, 87(5317):341-349.

5. Silva Y, C Contreras-Martel, Macheboeuf P, et al. Bacterial secretins: Mechanisms of assembly and membrane targeting[J]. Protein Science, 2020, 29(4):893-940.

6. Kepenek E S , Ozcinar E, Tuncay E, et al. Differential expression of genes participating in cardiomyocyte electrophysiological remodeling via membrane ionic mechanisms and $\mathrm{Ca} 2+$-handling in human heart failure[J]. Molecular and Cellular Biochemistry, 2020, 463(1):33-44.

7. Pokhrel R, N Bhattarai, Baral P, et al. Molecular mechanisms of pore formation and membrane disruption by the antimicrobial lantibiotic peptide Mutacin 1140[J]. Physical Chemistry Chemical Physics, 2019, 21(23):12530-12539.

8. Garaeva A A , Slotboom D J . Elevator-type mechanisms of membrane transport[J]. Portland Press Open Access, 2020, 48(3):263-278.

9. Sinerik, Ayrapetyan. The Quantum-Mechanical Sensitive $\mathrm{Na} / \mathrm{K}$ Pump Is a Key Mechanism for the Metabolic Control of Neuronal Membrane Function[J]. Journal of Biophysics, 2020(2):59-83.

10. Nepal B, Sepehri A, Lazaridis T . Mechanisms of negative membrane curvature sensing and generation by ESCRT III subunit Snf7[J]. Protein Science, 2020, 29(6).

11. Westerfield J M , Barrera F N . Membrane receptor activation mechanisms and transmembrane peptide tools to elucidate them[J]. Journal of Biological Chemistry, 2020, 295(14):1792-1814.

12. Jayashree $M$, Singhi $S$, Ray $P$, et al. Longitudinal comparative trial of antibiotic cycling and mixing on emergence of gram negative bacterial resistance in a pediatric medical intensive care unit[J]. Journal of Critical Care, 2020, 56:243-248.

13. Lim V T, Freites J A, Tombola F, et al. Thermodynamics and Mechanism of the Membrane Permeation of Hv1 Channel Blockers[J]. The Journal of Membrane Biology, 2020, 254(11):1-12.
14. Nikparvar B, Subires A, Capellas M , et al. A Dynamic Model of Membrane Recovery Mechanisms in Bacteria following High Pressure Processing[J]. IFAC-PapersOnLine, 2019, 52( 1): 243-250.

15. Bacellar I, Baptista M S . Mechanisms of Photosensitized Lipid Oxidation and Membrane Permeabilization[J]. ACS Omega, 2019, 4(26): 21636-21646.

16. Jiang $\mathrm{G}$, Liu $\mathrm{S}, \mathrm{Yu} \mathrm{T}$, et al. PAMAM dendrimers with dual-conjugated vancomycin and Ag-nanoparticles do not induce bacterial resistance and kill vancomycin-resistant staphylococci[J]. Acta Biomaterialia, 2021, 15(5):230-243.

17. Machado R, Lisa T, Arce C , et al. Engineering bacterial symbionts of nematodes improves their biocontrol potential to counter the western corn rootworm[J]. Nature biotechnology, 2020, 2020, 38(5):600-608. 